\title{
Carrying Out Research Among Persons WITH DISABILITIES AND THEIR RELATIVES - SeleCted ETHicAl IsSUES
}

\section{Marta Sałkowska*}

\begin{abstract}
The paper tackles issues related to selected both ethical and practical aspects of conducting research among persons with disabilities and their relatives that constitute a vulnerable social group. The author analyzes its consequences in the research process, discusses the significance of the research problem undertaken both for the development of academic knowledge and for research participants, and analyzes the conditions for obtaining informed consent. Limits of sociological interview and researcher's engagement are also discussed.
\end{abstract}

Keywords: Ethics, vulnerable social group, persons with disabilities, qualitative research

Creating the English-language version of the journal "Zoon Politikon" is financed under contract No. 724/P-DUN/2018 from the funds allocated by the Minister of Science and Higher Education for dissemination of science.

\footnotetext{
*Marta Sałkowska, Ph.D., Collegium Civitas, Warsaw, Poland, e-mail: marta.salkowska@civitas.edu.pl ORCID: https://orcid.org/0000-0002-8011-8214
} 
Introduction

This paper summarises my reflections on ethical issues associated with conducting research involving disabled people and their families. My objective, however, was not to analyse the various research principles and rules contained in the various codes and guidelines ${ }^{1}$, but rather to reflect upon the ethical dilemmas that I face when working on research projects involving people with disabilities.

Therefore, this paper is somewhat autoetnographic in nature as I use the experience and knowledge gained as a researcher to examine the various stages of research projects that I was involved in. My (auto)reflection draws on academic studies (individual in-depth interviews with mothers of Down syndrome children in Poland and Norway), application research (local research among disabled people, their families and social workers) and projects commissioned by public institutions (research on personal assistants commissioned by the Office of the Commissioner for Human Rights).

It should be noted that the discussed ethical issues apply chiefly to qualitative studies, and especially in-depth individual interviews, during which researchers interact directly with disabled people or their families. Quantitative studies do not involve as many challenging and ethically equivocal scenarios during "fieldwork" even if they do focus on "sensitive" data. Quantitative studies are decidedly more formalised and ordered².

\footnotetext{
' For example the "Ethical Guidelines" of the European Sociological Association, https://www.european sociology.org/about-esa/governance/ethical-guidelines; and the "Code of Ethics" of the International Sociological Association, https://www.isa-sociology.org/en/about-isa/code-of-ethics.

${ }^{2}$ Another issue that requires mentioning is the very limited statistical data available on people with disabilities in Poland. The challenges related to gathering such data are outline in: Raport dotyczacy wdrażania art. 31 Konwencji o prawach osób niepełnosprawnych $w$ Polsce: statystyka i zbieranie danych (2017), (Ed.) Grabowska I., http://www.pfon.org/images/dodatki/2017_konwencja_raport/RT_ art31_statystyka.pdf.
} 
I feel obliged to explain why it were the ethical issues of conducting research in such a special community that I chose to analyse. The choice was purely subjective. Having spent a lot of time and gained a lot of experienced in that field, I decided that ethical issues have had a substantial impact on my work as a researcher and on the research projects that I took part in. That is why I decided to focus on that aspect of my work.

It has to be said that ethical issues are an inherent part of any research project involving people, not only those that focus on vulnerable social groups. Yet, given the scarcity of quantitative studies on people with disabilities and insufficient research field's exploitation of the disabled community (which is covered in more detail later in this paper), I deemed it necessary to focus on the ethical aspects of research on disabled people. I have intentionally intertwined the analysis of said ethical aspects with descriptions of research practices. That is because the manner in which research is carried out relies on the ethical principles of the researchers which permeate all stages of the research process.

I also feel obliged to explain why I chose to adopt an auto-reflective / autoetnographic approach to the issue. I do not consider myself as the definitive expert on ethical issues in research in general, and in disability studies in particular. It is definitely not the case that I am the sole academic interested in that topic. Sociologists do analyse and examine disabilities. They employ diverse theoretical and methodological approaches, gathering both quantitative and qualitative data. Disability has recently been brought up in public debate, albeit briefly, for example during the carer protests of 2018.

It is those short moments of media and public opinion attention that set out an important context for my reflections. Disability is no longer ignored as more and more people speak up about it, and along with that comes growing interest among academics (not only resulting in gather- 
ing statistics, but also devising new interpretations of the phenomenon). This paper gives me the opportunity to share my thoughts about my research methods concerning a topic that is growing more intriguing academically, socially and culturally. The auto-reflective nature of this paper means that it is strongly rooted in Polish reality.

The social vulnerability of people with disabilities and their families and the impact that it has on research

People with disabilities and their families constitute a vulnerable and inaccessible social group. Its vulnerability is mainly a result of the double stigmatisation that is especially apparent among mothers of children with Down syndrome and carers (especially female carers) in general (Liamputtong 2007, p. 3).

On the one hand, mothers of children with Down syndrome (or with any other disability) may be stigmatised solely due to their children being disabled ${ }^{3}$. Such women often fall victim to a wide array of prejudices and stereotypes, including being blamed for their child's mental disability which is sometimes seen as "God's wrath" for "immoral behaviour".

On the other hand, the consequences of "special maternity" are the key factor shaping a woman's lifestyle. Inefficient support systems and social policies may sometimes prevent mothers from assuming any other social roles than "just" mothers. Mothers of disabled children, however, also have to act as physiotherapists and speech therapists among others.

Yet, the above roles are rarely social as they are performed in a private setting, i.e. at home. The controversy surrounding the protests of disabled adult children's parents and carers held at the parliament have unleashed the true magnitude of the above issue. Carers, and especially

${ }^{3}$ A detailed description of the lives of mothers of Down syndrome children is provided in: Sałkowka 2015. 
carer mothers, often have to spend all of their time at home which prevents them from taking part in any outside activities. Furthermore, the diversity, or lack thereof, of social roles that one performs has a positive impact on their feeling of self worth as well as their capability and courage to face up to stigmatisation and its consequences (Thoits 2011, p. 19).

The respondents' exclusion from participating in public life makes it harder for researchers to reach them, which may lead to further stigmatisation. That, in turn, results in a shortage of reliable information on issues faced by disabled people and their families, and thus a lack of knowledge among "normal" people who do not regularly come into contact with disability (professionally or privately). The above circumstances create a vicious cycle of exclusion and stigmatisation stemming from a lack of knowledge, often leading to stereotypical and unfair perception and treatment.

Rules and boundaries - what is a sociological interview?

Research involving vulnerable social groups requires considerable patience, gentleness and a thorough explanation of the rules. It is necessary to establish clear boundaries. Participants have to be made aware of the purpose of the project as well as the researcher's responsibilities and obligations. They should be assured that their personal data and statements will remain confidential and anonymous. The above conditions have to be met if one wishes to obtain informed consent to take part in the project from respondents.

I conducted in-depth interviews with mothers of children with Down syndrome in Poland and Norway ${ }^{4}$ I noticed discrepancies in the degree

4 The research in Norway was made possible by funding received from the Scholarship and Training Fund and was carried out during two research trips to Trondheim (in 2009 and 2011). 
to which ethical issues are formalised in the two countries. Visiting researchers in Trondheim are required to obtain a decision from the ethics committee of their university (or their thesis supervisor in the absence of such committee) before being allowed to carry out research. The accepted practice in Poland is that the thesis supervisor, seminar group or research team are required to assess the research project, including matters relating to ethical principles (Ciuk, Latusek-J urczak 2012: 25-26). The process of obtaining consent is considered to be formalised when informed consent is obtained from respondents.

Norwegian respondents were not surprised when I asked them to sign a consent form which listed their rights and my obligations towards them and the data that I intended to gather. Nor were they surprised when I informed them that the interview will be recorded.

I, on the other hand, was surprised that not one of them expected me to explain the reasons for recording or required persuading. On thecontrary, respondents saw recording as something obvious.

Their attitude towards interviews and research may have been shaped by earlier participation in social research projects. I obtained the personal data of my Norwegian respondents by contacting researchers who were based at the local university and conducted studies on disabilities. It is very likely that their reliability and engagement made respondents more willing to take part in my research. Therefore, my initial experiences consisting in gaining access to respondents and obtaining their consent was very positive.

Among the gate-keepers in Poland was a speech therapist working at a disability centre, a psychologist based at an early intervention centre and employees of an association of families of Down syndrome children. I also employed the help of my associates and placed an ad on an online discussion board to reach respondents. Most of my Polish respondents were surprised when asked to sign a consent form, some 
were reluctant to consent to being recorded, and one participant outright refused to be recorded.

I began to wonder what lays at the cause of the differences in attitudes of Polish and Norwegian respondents. The overall social trust level may be a factor (respondents may be afraid that their statements will be published or otherwise used without ensuring anonymity) as may be the generally negative perception of research and researchers in Polish society. I also suspect that the practice of obtaining written consent from respondents is not widespread in Poland due to researchers being concerned that refusals would be commonplace.

It is worth noting that the contract signed by both the researcher and respondent serves to formalise the entire situation and provides a framework within which it functions. First and foremost, it precisely defines the interaction as a sociological, and not therapeutic, interview. The researcher's role is to ask questions aimed to produce answers providing information on a specific research goal. The respondent, on the other hand, is not taking part in a therapy session, but rather shares information on the topic of the study. Despite offering a detailed explanation of what a sociological interview, setting boundaries and adopting a professional approach, it often proves challenging or even impossible to avoid the interview becoming therapeutic.

It should be stated that sociologists do not have the capacity to provide therapeutic support. What we can and should do, however, is ensure that our respondents feel as safe and comfortable as possible. It is also necessary to build a good relationship. Sometimes we have to contribute to the relationship to build trust - a sociological interview is an exchange-based interaction. Therefore, researchers should avoid treating respondents instrumentally (cf. Ciuk, Latusek-J urczak 2012, pp. 33-34).

A different perspective should be adopted. Do bear in mind that respondents are expected to talk about very personal events, and many of 
your interviewees have never had the opportunity to talk about their lives in such a sincere and open manner. Thus, they need to know the person to whom they will be relating their story.

There is one additional issue that should be made clear when obtaining consent for interviews: sociological interviews are not community interviews and therefore will have no bearing on the provision of psychological, material or social support. I realised this when working on a research project on personal assistants of disabled people commissioned by the Office of the Commissioner for Human Rights. We had reached respondents via various non-governmental and support organisations. Many respondents called us afterwards asking if they would be assigned a personal assistant.

Therefore, it is necessary to outline the goals of your research and state what will be expected from participants at the initial stages of respondent recruiting. The institutionalisation of the research project has a definite impact on the manner in which respondents perceive the interviews that they take part in. If the research is commissioned by Social Welfare Centres or the Office of the Commissioner for Human Rights, respondents may expect to receive tangible benefits as compensation for their participation. Whereas if the project is academic in nature, the results expected by respondents will likely be intangible, that is not to say less important.

Whose informed consent do you need?

Obtaining informed consent to take part your research project (both oral and written) raises some dilemmas regarding the manner in which information concerning research goals, analysis methods and theoretical frameworks should be shared. The researcher is obliged to provide detailed information upon the request of respondents. Thus, the re 
searcher is required to clearly explain his or her research goals and ensure that respondents understand them. There is no need to present the theoretical frameworks used (unless respondents ask about them) or provide detailed descriptions of analysis methods. You should provide enough information for the respondent to be able to express informed consent to take part in the research.

The matter becomes more complicated when you are trying to obtain consent from a person who is disabled or suffers from a condition that prevents them from being able to make a decision independently. In such cases, the researcher should try to explain what the research entails in very simple terms or obtain consent from the person's carer. We should, however, attempt to enable disabled people to make informed decisions on the matter.

This is a very delicate issue that had a substantial impact on my research into personal assistants of disabled people (commissioned by the Office of the Commissioner for Human Rights). One of the objectives was to explore what people with various disabilities expect from assistants. Among the respondents were individuals with mental disabilities. Such people are particularly inaccessible as all interactions with them are usually indirect, with parents, carers and various specialists speaking on their behalf.

The reason given is that mentally disabled individuals are difficult to communicate with. Parents often wish to speak for their (adult) mentally disabled children. Our study, however, did not allow for such scenarios. The end result was that we did not manage to conduct all of the interviews that we had planned.

Of particular note is the key role played by gate keepers or carers who have the definite say over a respondent's decision. The researcher's goal is to ensure that the respondent expresses informed consent and understands what his or her participation in the study entails (along with being aware of the possibility to quit the interview at any moment). 
Some respondents were living at Social Nursing Homes (SNH). They were selected by $\mathrm{SNH}$ employees (the management and on-site psychologists) in accordance with the socio-demographic criteria presented by the research team. Each interview started with a thorough explanation of the rules followed by asking respondents whether they agree to take part in the interview. Despite being assured of the respondents' consent, I nevertheless wonder whether their decisions were made independently. The respondents might have simply submitted to the will of SNH management and the on-site psychologist, or decided to take part in the research to please the latter.

J akub Niedbalski raised a similar question (2009) when describing the ethical issues relating to conducting observations at social nursing homes for the mentally disabled. In that case, participant observation was selected as a research method due to the possible communication difficulties when conducting interviews. The author notes, however, that there are doubts whether subjects may be provided adequate intimacy and rest while living in a care institution.

Difficulties are also encountered when interviewing respondents with hearing disabilities. Researchers who do not speak sing language have to seek the assistance of an interpreter (which brings on additional expenses and introduces a third person into the interview) or a remote interpreter.

I often made use of the "shallow cover" strategy when obtaining informed consent from respondents (Lofland et al. 2009). I avoided details preferring instead to talk about my research in general terms. My view was that respondents could ask me questions if they wanted to find out more. The interviews themselves were complicated enough, mostly organized through a very inaccessible private setting. Therefore, I did not want to make the situation more complicated that it had to be.

I try to present the research topic and goals in a straightforward manner without resorting to academic jargon. When conducting 
research involving mothers of Down syndrome children, I told my respondents that I was working on a doctoral thesis focusing on the experiences of mothers of Down syndrome children (including also teenagers and adults). I purposefully avoided using the term "stigma" despite it being crucial in my analysis of the obtained data. I did not want to hint at my thoughts and perspective. Also, I thought that using that word could make my respondents feel uncomfortable. Respondents were informed that my responsibilities include protecting their privacy and that the interviews would remain anonymous.

Adrianna Surmiak (2016) describes the various ways in which information concerning research and its goals may be presented to manipulate respondents in order to attract them and spark their interest. She notes that obscuring the true purpose of research impacts respondents' perceptions of its goals and "nature".

It turns out that such manipulation may be deemed ethical depending on the ethics code used in a given discipline (ethnology, anthropology, sociology). That further proves my conviction that the researcher, using his or her academic judgement, is responsible for honestly presenting his or her research project and obtaining informed consent from respondents.

An important issue, but for whom?

The fact that results of various past studies (carried out for the needs of master's and doctoral theses) have not been published may raise questions regarding the relevance of the present paper's topic.

Relevance, remarks Uwe Flick (2010), is one of the first questions and ethical dilemmas that a researcher faces when designing a study. Researchers should verify whether someone has already explored the topic as early as in the problematisation stage. If so, there is no reason to do it again. There may however be data available that could prove 
useful. The main point is that one should avoid needlessly engaging respondents. Therefore, it is crucial to prepare the research well, including a solid theoretical foundation and a thorough analysis of available data.

Apart from considering the relevance of the chosen topic for broadening academic knowledge, one should also consider the relevance that the topic has for respondents. Upon deciding to carry out research into a vulnerable social group, one should make the assumption that the research may somehow impact the lives of respondents (Liamputtong 2007, pp. 10-11). We assume, of course, that the impact will be positive and participation in the research will improve the lives of respondents.

When researchers are free to choose the topics of their research, the only determining factors are the researcher's personality and, in some cases, fate. When you choose a topic related to disadvantaged people, you have to decide whose side you will take. Will your research give a voice to those who cannot speak up for themselves? Will you side with those who shape social policies? Or will you rather choose to speak out on behalf of the clients of social services providers?

When you adopt someone else's perspective, you may be seen as biased. Howard Becker (1967) remarked that such accusations are usually put forward when the experiences of so-called ordinary people, and not experts, are taken into consideration. Using terminology borrowed from descriptions of hierarchical relationships, Becker puts ordinary people in the role of subordinates, whereas experts, officials and professionals are their superiors. In Becker's view, you should not ask yourself if you are going to take sides, but rather decide whose side you are on, as wealways view the issue at hand from someone's perspective and base our perception on their experience. That is the reason why Becker recommends preparing well to be ready to face up to accusations of bias and free ourselves from unnecessary emotions. 
We could also reframe the issue in line with the critical theory paradigm - can we as researchers side against the weaker and underprivileged group? We should take advantage of the possibilities that our work opens up and use our research to "give voice" to people who would otherwise remain silent (cf. Creswell 2007).

There is no doubt that assessing the extent to which our research will improve the lives of our respondents and other members of the disadvantaged groups that they belong to is difficult. Will the research actually change social attitudes, improve social services and social policies? Will it diminish the social exclusion of and discrimination against families with disabled children?

When considering the benefits of research projects, one must not forget their impact on individuals. Maybe we should ask ourselves: what will the respondents gain from taking part in the research? One participant stated that sharing her story may help other women who are dealing with similar problems. That was her motivation. Also, her likeminded daughter encouraged her to go through with it.

Furthermore, in many cases interviews are the first time that the mothers of mentally disabled children are given the opportunity talk about their experiences. They infuse their story with their own meanings, tell it from their perspective, using their own words and expressions that lie outside of the professional vernacular.

In that way, participating in research takes on an emancipatory and empowering character (cf. Chase 2009). On the other hand, some re searchers demand that the "right of respondents to be kept in the dark" (cf. Ciuk, Latosek-J urczak 2012, p. 34) be respected, i.e. respondents should not be encouraged to share information and insights that they would not have shared if they had not take part in the research.

The above approach brings up many questions, some of which concern the very practical aspects of the entire research process, e.g. how to recruit respondents? How can we assess whether or not we are likely 
to breach the "right to be kept in the dark" at the respondent recruiting stage of the project? Can weassume that an adult who is informed about the goals of the research and his or her right to terminate the interview at any moment, who we know has understood his or her role and expressed informed consent, to also agree to the possible emotional distress that he or she may encounter (e.g. remembering and reliving painful events, experiences)?

\section{Emotions}

Researchers have to be prepared to handle the emotional reactions of respondents due to the sensitive subject matter of the interviews. My psychologist friend advised me to always have a pack of tissues on hand during interviews in case my respondent starts to cry. The gesture of handing her a tissue shows that the interviewer accepts her emotions, is not surprised by them and is ready to wait for them to calm down before they continue their conversation. Thus, I was prepared for the strong rush of emotions that the interview could cause in my respondents. I accepted that and was able to predict when such outbursts would take place.

I was more surprised by my own emotional reaction - I was not prepared for it and therefore found it harder to deal with. Psychologists undergo clinical supervision sessions where they discuss challenging cases, share advice on how to behave in certain situations, describe how they feel when conversing with their clients, i.e. talk about their emotions. Sociologists also feel strong emotions when conducting interviews, especially in-depth interviews on difficult, personal topics.

I often felt a sense of guilt when listening to the stories of my respondents because my child is not disabled and, therefore, my life is nowhere near as difficult as theirs. I often felt angry at my respondents. 
I did not agree with their views on their situation in life and their approach to the disabilities of their children. I could not understand why they behave the way that they do. I tried not to let my emotions show. Obviously, I knew that I was in no position to judge my respondents. Nevertheless, I did feel strong emotions.

That is why I decided to keep a research diary which would allow me to record my feelings and opinions. Upon later reading I found that the women that I had interviewed did the best that they could in the circumstances. They gave all that they had to give. They wanted the best for their children, albeit their definitions of what was best differed.

I think that it is necessary to be aware and ready to face the emotions that research into sensitive topics will surely evoke. It is necessary for the researcher to remain vigilant and constantly analyse what is happening during the interview. When you sense an emotionally challenging moment approaching, you sometimes have to make a quick decision - should you keep on pressing the subject or "let it go?" Decide what is more important - sticking to the script or caring for the emotional well-being of the respondent. Each interview requires the researcher to determine the boundaries that he or she should not cross as to not upset their respondent. Researchers should take particular care not to violate those boundaries (Flick 2010).

Such flexibility and ability to back down from discussing certain topics can, for the most part, be only afforded by academics who are conducting their own research. If the study is commissioned by some institution, for instance, there may not have that choice.

Summary 
Pranne Liamputtong (2007) emphasises that more attention should be given to the research process when dealing with vulnerable social groups. More thought should be given to the manners in which research influences not only respondents, but also researchers. We seem to forget that researchers gain experience, not only professional but also emotional and personal, with each subsequent project that they work on. Our research changes us. Exploring challenging topics keeps us learning.

We sometimes feel detached from social reality. We have a tendency to reduce the human condition to numbers, percentages and other kinds of enumerable data. That approach makes it easier to handle our job and the associated emotions. I feel that we give too little thought the role of the researchers and the methods that they use to deal with their own emotions and difficulties when conducting research involving vulnerable social groups.

The concept of boundaries is key when analysing vulnerable social groups. The research scenario, i.e. the in-depth interview, relies on boundaries and frameworks. They are set out by the researcher's responsibilities, the rights of the respondents and the generally accepted and codified rules. Obtaining formal consent from respondents protects both the researcher and the respondents. The boundaries are fluid and vary depending on the researcher, respondents and the context in which the interviews take place.

Where lies the boundary between a sociological interview and a conversation (having similarities to a therapeutic session)? How far can the researcher go before he becomes the respondent's "friend"? Can gathering data be separated from becoming involved in the lives of the respondents? How much does the researcher have to contribute, how much of themselves do they reveal?

Such matters cannot be codified and are up to the discretion of researchers and respondents. 
References

Becker H.S. (1967), Whose side are we on?, „Social Problems” Vol. 14 Ciuk S., Latusek-J urczak D. (2012), Etyka w badaniach jakościowych [Ethics in qualitative research], (in:) Badania jakościowe. Podejścia i teorie. Tom I [Qualitative Research. Approaches and Theories. Volume I], (Ed.) J emielniak D., Wydawnictwo Naukowe PWN, Warszawa

Chase S.E. (2005), Narrative Inquiry: Toward Theoretical and Methodological Maturity., (in:) The Sage Handbook of Qualitative Research. $3^{\text {rd }}$ Edition, (Eds.) Denzin N.K., Lincoln Y.S., Sage Publications, Thousand OaksLondon- New Delhi

Creswell J.W. (2009), Qualitative Inquiry \& Research Design. Choosing Among Five Approaches, Sage Publications, Thousand Oaks

Flick U. (2007), Designinh Qualitative Research, Sage Publications, Thousand Oaks- London- New Delhi- Los Angeles- Singapore-Washington

Liamputtong P. (2007), Researching the Vulnerable. A Guide to Sensitive Research Methods, Sage Publications, London- Thousand Oaks- New Delhi

Lofland J., Snow D.A., Anderson L., Lofland L.H. (2006), Analyzing Social Settings: A Guide to Qualitative Observation and Analysis, Wadsworth Thomson, Belmond CA.

Niedbalski J . (2009), Niepetnosprawność intelektualna $w$ perspektywie badan socjologicznych. Rozważania nad zastosowaniem metod jakościowych [Intellectual disability in the perspective of sociological research. Considerations on qualitative methods' application], (in:) Metody, techniki i praktyka badań spolecznych [Methods, techniques and practice of social research], (Eds.) Bąk A., Kubisz-Muła Ł., Wydawnictwo Akademii Techniczno-Humanistycznej, Bielsko-Biała

Sałkowska M. (2015), Matka Downa. Piętno. Znaczenia. Strategie [Down's Mother. Stigma. Meanings. Strategies], Zakład Wydawniczy NOMOS, Kraków 
Surmiak A. (2016), Wybrane problemy etyczne $w$ naukowych badaniach na zlecenie. Refleksje etnografki [Some Ethical Issues in Contract Research. Ethnographer's Reflections], „Przegląd Socjologii Jakościowej”, t. 12, nr 3, http:// www.qualitativesociologyreview.org/ PL/Volume35/PSJ_12_3_Surmiak.pdf

Thoits P.A. (2011), Resisiting the Stigma of Mental Illness, "Social Psychology Quarterly"Vol. 74, No. 6 